\title{
Toxicity of root canal sealers in vitro
}

\author{
Anil Chandra ${ }^{1 \dagger}$, Hena Rahman ${ }^{2 *}$, Amita Agarwal ${ }^{3 \dagger}$ and Arun Verma ${ }^{4+}$ \\ *Correspondence: henavns@gmail.com

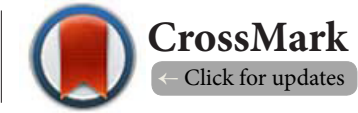 \\ 'These authors contributed equally to this work. \\ 'Department of Conservative Dentistry and Endodontics, Faculty of Dental Sciences, King George's Medical University, \\ Lucknow, India. \\ ${ }^{2}$ Department of Conservative Dentistry and Endodontics, Career Post Graduate Institute of Dental Sciences and Hospital, \\ Lucknow, India. \\ ${ }^{3}$ Department of Pedodontics and Preventive Dentistry, Saraswati Dental College, Lucknow, India. \\ ${ }^{4}$ Department of Conservative Dentistry and Endodontics, Sardar Patel Post Graduate Institute of Dental and Medical \\ Sciences, Lucknow, India.
}

\begin{abstract}
Objective: To comparatively evaluate the cytotoxicity of EndoREZ (urethane dimethacrylate based), RoekoSEAL (silicone based) and Kalsogen Plus (ZOE based) sealers on HEK-293 (human embryonic kidney epithelial cells) and Vero (African green monkey kidney epithelial cells) cell lines in vitro.

Materials and methods: Sealers EndoREZ, RoekoSEAL and Kalsogen Plus were mixed according to manufacturer's instructions. Extract of these sealers were then treated with cultured cell (HEK-293 and Vero), cytotoxicity evaluated using MTT assay.

Cytotoxicity between fresh and set specimens at $0 \mathrm{~h}, 24 \mathrm{~h}, 48 \mathrm{~h}, 72 \mathrm{~h}$ and $1 \mathrm{wk}$ time-interval were calculated. Statistical analysis was done using SPSS Version 15.0 (SPSS, Inc., Chicago, IL, USA) statistical software package $(\mathrm{p}<0.05)$.

Results: Extracts of Kalsogen Plus were more toxic, as compared to all other groups $(\mathrm{p}<0.05)$ on both cell lines. The mean value of EndoREZ was significantly lower as compared to all other groups on both cell lines. The mean value of RoekoSEAL was significantly higher as compared to EndoREZ but significantly lower as compared to Kalsogen Plus.

Conclusion: Kalsogen Plus and RoekoSEAL were slightly cytotoxic while EndoREZ was non-cytotoxic on both cell lines. The cytotoxic response decreased in the order of Kalsogen Plus $>$ RoekoSEAL $>$ EndoREZ overtime.
\end{abstract}

Keywords: Toxicity, root canal sealers, MTT assay, inhibition

\section{Introduction}

Root canal sealers are used for assisting in formation of hermetic seal during obturation of root canal [1]. Endodontic sealer should be selected on the basis of various physical as well as biological parameters, such as local and systemic biocompatibility [2]. Biocompatibility of these materials is important as root canal sealers frequently come in contact with soft and hard tissues, if extruded during root canal treatment [3]. Ideally a sealer should not hinder tissue repair, but aid or stimulate the reorganization of injured structures $[1,4]$. The success of root canal treatment is influenced by these materials [5]. Therefore, the biocompatibility of these materials is of utmost importance [6].

It is evident that the biological risks of endodontic sealers is relatively high, as the components of various root canal sealers may induce potential tissue toxicity, leading to apical periodontal tissue damage and inflammatory responses $[7,8]$. Unfortunately these materials might remain in close contact with periapical tissues for long periods. Even in cases where the sealer does not reach directly the periapical region, there is always the possibility of elutable substances leaching through the dentinal tubules, lateral and accessory canals or apical foramina [9]. Perforation of root also creates communication between the root canal system and the periodontal ligament [10] However, Ørstavik in 2005 concluded that primary infection or infection secondary to root filling procedures is the principle cause of apical periodontitis and endodontic failure [11].

Nasseri et al., performed a study to evaluate the apical and periapical tissues responses after root canal obturation with two calcium hydroxide based sealers in dog's teeth, they concluded that regardless of the sealer used, there were observed necrosis in a few of delta apical's ramifications and inflammation of both apical and periodontal tissues [12]. Therefore, it is required that effect of sealers on apical and periodontal tissues should be well known before their use.

Different classes of root canal sealers have shown varying amount of cytotoxicity [13-16]. Resin based sealer are most commonly used now because of their better adhesion to dentinal wall, radioopacity and uniform sealing ability $[17,18]$. EndoREZ (Ultradent Products, Inc., South Jordan,UT, USA) is a single methacrylate based sealer which contains UDMA (Urethane Dimethacrylate), maximum working time of 12-15 minutes and it will begin to polymerize in the canal at that time [19]. It has 
hydrophilic characteristics providing excellent penetration into dentinal tubules [20]. This allows for improved sealing properties combined with ease of placement and removal. The sealer has shown biocompatibility to periapical tissues in subhuman primates [21] and to rat cells and bone tissue [22].

The silicone-based endodontic sealer, RoekoSeal (Colte'ne Whaledent, Langenau, Germany), has been reported to be noncytotoxic [23] or slightly cytotoxic [24]. RoekoSeal is a polydimethylsiloxane based root canal sealer. It has chemical and physical properties that exhibit extremely high sealing ability and biocompatibility, has a setting time of $45-50$ minutes and appears to be less cytotoxic than sealers based on methacrylate, zinc oxide-eugenol and epoxy resin [24]. However, another study rated the silicone based sealer equal to an epoxy resin-based sealer in terms of cytotoxicity [25].

Kalsogen ${ }^{\circledR}$ Plus is a polymer reinforced fast setting zinc oxide eugenol cement in a light-yellow shade corresponding to Vita ${ }^{\circledR}$ B2 and Biodent 15 . Kalsogen ${ }^{\circledR}$ Plus complies with the specification of ISO 3107, Type III, Class I, for temporary restorative materials and base materials. Working time is 2 mins from end of mix at room temperature of $23^{\circ} \mathrm{C}$ and $50 \%$ relative humidity. Zinc oxide-eugenol-based endodontic sealers have been used for many years but release potentially cytotoxic concentrations of eugenol $[26,27]$. Eugenol is found to leak from zinc oxide-eugenol sealers [28]. Both zinc oxideeugenol and eugenol induce a toxic effect in cell culture models [29] and reduce the transmission in nerve cells [30]. The effects are persistent, also after setting of the material.

\section{Materials and methods}

\section{Biological cell lines used in the study}

The human embryonic kidney cells (HEK-293) were obtained from a healthy aborted foetus and originally cultured by Vander Eb of Holland.

The Vero lineage was isolated from kidney epithelial cells extracted from an African green monkey (Cercopithecus aethiops). The lineage was developed in 1962, by Yasumura and Kawakita at the Chiba University in Chiba, Japan.

The standardized cell culture methods and the frequently used MTT assay, employing target cells, are well recognized methods for assessing dental materials nonspecific cytotoxicity. MTT [3-(4,5-dimethylthiazole-2-yl)-2,5-diphenyltetrzolium bromide)] is dye which on oxidation converted in to purple coloured formazan crystals of substrate. Live cell mitochondria contains cytochrome oxidase enzyme which converts the MTT dye in to its coloured substrate. Thus percentage of live cell in the population can be quantified by measuring the absorbance at $540 \mathrm{~nm}(\mathrm{OD})$ of treated versus untreated cells.

The present study was performed in vitro. Samples prepared were divided in to two main groups - untreated control group and experimental group (sealers used in the study). Control group is DMEM (Dulbecco's Modified Eagle's Medium) alone. DMEM is a modification of Basal Medium Eagle that contains four fold concentrations of the amino acids and vitamins.
Experimental groups are depicted in (Table 1).

Table 1. Control and Experimental Groups used in Study.

\begin{tabular}{lll}
\hline Groups & Materials used & Composition \\
\hline Control Group & DMEM media alone & $\begin{array}{l}\text { Dulbecco's Modified Eagle's } \\
\text { Medium }\end{array}$ \\
Experimental Groups & Sealers used in study & -- \\
gp-I & ER (EndoREZ) & $\begin{array}{l}\text { dual-curing contains zinc } \\
\text { oxide, barium sulfate, resins, } \\
\text { and pigments in a matrix of } \\
\text { urethane dimethacrylate }\end{array}$ \\
& RS (RoekoSEAL) & $\begin{array}{l}\text { Polydimethylsiloxane, } \\
\text { Silicone oil, Paraffin-base oil, } \\
\text { glatinum catalyst, Zirconium } \\
\text { dioxide }\end{array}$ \\
powder contains zinc oxide \\
gp-III & ZOE(Kalsogen Plus) & \begin{tabular}{l} 
liquid contains eugenol \\
\hline
\end{tabular}
\end{tabular}

\section{Cell culture and preparation of extract}

All the experimental sealers (Endorez, RoekoSeal and Kalsogen Plus) were mixed according to manufacturers' instructions under aseptic environment. Extracts were prepared aseptically under laminar flow hood. DMEM (phenol free) is used for preparing the root canal sealer's extract. The materials were then placed in non-reactive 12 well plates and allowed to set according to the manufacturers' instructions at $37^{\circ} \mathrm{C}$. Fresh extracts (FE) were collected immediately after mixing by adding $2 \mathrm{ml}$ DMEM and then kept for 5 minutes. After that extract was collected; syringe filtered and then stored at $-20^{\circ} \mathrm{C}$ till further use. $0 \mathrm{hr}$ extracts (OE) were collected after setting of mixed root canal sealers in the same way as freshly mixed extract. $24 \mathrm{hr}$ extracts (24E) were collected $24 \mathrm{hr}$ after setting of mixed root canal sealers. After setting of mix $2 \mathrm{ml}$ of DMEM was added and allowed to incubate at $4^{\circ} \mathrm{C}$. Extracts were then collected after $24 \mathrm{hr}$. Similarly, $48 \mathrm{hr}(48 \mathrm{E}), 72 \mathrm{hr}(72 \mathrm{E})$ and 1 week(1Wk) extracts were collected.

Cell lines HEK-293 and Vero were propagated in minimum essential medium, supplemented with $5 \%$ foetal bovine serum (Invitrogen, USA), $2 \mathrm{mmol} / \mathrm{L}$ L-glutamine, $100 \mathrm{U} / \mathrm{mL}$ penicillin (Gibco-BRL, USA) and $100 \mu \mathrm{g} / \mathrm{mL}$ streptomycin at $37^{\circ} \mathrm{C}$ in air atmosphere containing $5 \% \mathrm{CO} 2$ and $95 \%$ relative humidity. Cells were passaged by treatment with trypsin-EDTA in phosphate-buffered saline solution.

Extract of each material was filtered using Millex-GS sterile filter (Millipore,USA) and used as the experimental material. A volume of $20 \mu \mathrm{L}$ of filtered extracts in $200 \mu \mathrm{L}$ medium (control) was added to each well containing cell lines used in the study along with DMEM media. Six replicates were used for each sample. Cells were incubated for $2 \mathrm{hr}$ at $37^{\circ} \mathrm{C}$ and $5 \%$ $\mathrm{CO}_{2}$. The $\mathrm{pH}$ of the extracts was checked using $\mathrm{pH}$ indicator strips (Decibel instrument, India). The MTT assay was carried out according to Mossman T (1983) to evaluate cytotoxicity of samples [31]. 
Chandra et al. Oral Biology and Dentistry 2014,

http://www.hoajonline.com/journals/pdf/2053-5775-2-2.pdf

doi: $10.7243 / 2053-5775-2-2$

Cells were taken after 80-90\% confluency. Media was decanted and washed with PBS $\left(6 \mathrm{ml}\right.$ for $25 \mathrm{~cm}^{2}$ and $10 \mathrm{ml}$ for $\left.75 \mathrm{~cm}^{2}\right)$. Cell were trypsinized by using $0.25 \%$ trypsin and split accordingly. Cells were then stained with $0.5 \%$ of trypan blue and viable cells were counted with the help of a hemocytometer. $20 \mu \mathrm{l}$ of cell suspension was added to $80 \mu \mathrm{l}$ of $0.5 \%$ of Trypan blue stain and mixed thoroughly in a sterile $1.5 \mathrm{ml}$ micro centrifuge tube. There after $10 \mu \mathrm{l}$ of the mixture was filled in a hemocytometer for cell counting. Under a microscope, viable cells were observed and average no of cells were calculated according to the given formula:

NO of cells $=$ Average No of cells $x$ Dilution Factor $x$ Counting Factor

Calculation of percentage of inhibition of cell growth/cytotoxicity was calculated with the formula given below -

$\%$ of Cell Growth Inhibition = [\{(Mean O.D. of Control) $-($ Mean O.D. of the Treated)\}/\{Mean O.D. of Control\}] x100

The formazan content of each well was computed as a percent of the control group (untreated cells). Cytotoxicity responses were rated as severe $(>70 \%)$, moderate $(40-70 \%)$, mild/slightly (10-40\%) or noncytotoxic (<10\%) [32].

The statistical analysis was done using SPSS Version 15.0 (SPSS, Inc., Chicago, IL, USA) statistical software package. $\mathrm{p}$-values $<0.05$ were considered statistically significant. The values were represented in Number (\%) and Mean \pm SD. Statistical values for each group of data were subsequently calculated with analysis of variance.

\section{Results}

As shown in (Tables 2 and 3), Kalsogen Plus showed highest mean value at $24 \mathrm{hr}$ on both cell lines. EndoREZ and RoekoSEAL had highest mean value at $48 \mathrm{hr}$ on both cell lines $(p<0.05)$. Data also showed that in all the type (HEK-293 and VERO cells) and point of time (Fresh, $0 \mathrm{hr}, 24 \mathrm{hr}, 48 \mathrm{hr}, 72 \mathrm{hr}$ and 1 wk), EndoREZ had the minimum cell inhibition and Kalsogen Plus had maximum $(p<0.001)$ (Figures 1 and 2$)$.

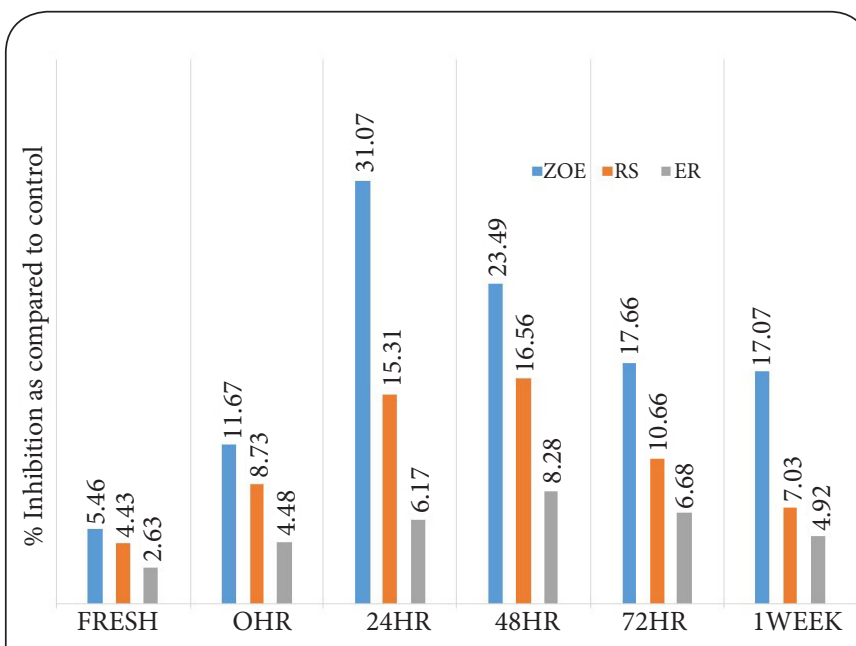

Figure 1. Showing \% inhibition zones of sealers on HEK cells, where $\mathrm{ZOE}=$ Kalsogen Plus, RS=RoekoSELL, ER=EndoREZ at different time intervals.

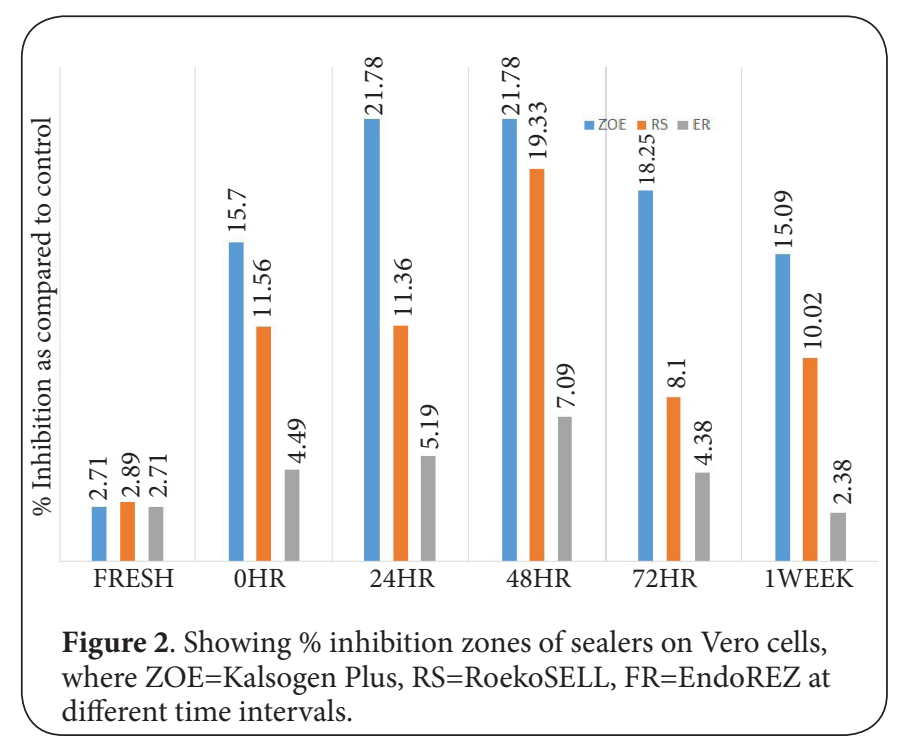

Table 2. Showing \% inhibition/cell cytotoxicity of sealers on HEK cells, where, ZOE=Kalsogen Plus, ER=EndoREZ, and RS=RoekoSEAL.

\begin{tabular}{lllllll}
\hline \multicolumn{6}{c}{ \% Cell Cytotoxicity (Mean \pm SD) } \\
\hline Sealers & Fresh & 0hr & 24h & 48h & 72h & 1 week \\
\hline ZOE & $5.46 \pm 1.86^{\mathrm{a}}$ & $11.67 \pm 1.64^{\mathrm{a}}$ & $31.07 \pm 2.86^{\mathrm{a}}$ & $23.39 \pm 2.00^{\mathrm{a}}$ & $17.66 \pm 5.08^{\mathrm{a}}$ & $17.07 \pm 5.02^{\mathrm{a}}$ \\
ER & $2.63 \pm 1.43^{\mathrm{b}}$ & $4.48 \pm 1.26^{\mathrm{b}}$ & $6.17 \pm 0.87^{\mathrm{b}}$ & $8.28 \pm 1.87^{\mathrm{b}}$ & $6.68 \pm 2.80^{\mathrm{b}}$ & $4.92 \pm 1.53^{\mathrm{b}}$ \\
RS & $4.43 \pm 0.61^{\mathrm{ac}}$ & $8.73 \pm 1.41^{\mathrm{ac}}$ & $15.31 \pm 3.01^{\mathrm{c}}$ & $16.56 \pm 4.82^{\mathrm{c}}$ & $10.66 \pm 3.30^{\mathrm{bc}}$ & $7.03 \pm 3.51^{\mathrm{bc}}$ \\
\hline
\end{tabular}

For each column, data with different letter superscripts denote significant difference $(\mathrm{p}<0.05)$. As compared to ZOE the mean value of all the other groups was found to be significantly ( $p=.000$ versus ER, $p=.000$ versus $R S$ ) different. The mean value of ER was minimum and significantly different as compared to all the other groups. RS had significantly lower mean value as compared to ZOE but significantly higher mean value as compared to ER. None of the other comparisons was significant statistically. Overall the increasing order of toxicity on HEK-293 follows $-\mathrm{ER}<\mathrm{RS}<\mathrm{ZOE}$. 
Table 3. Showing \% inhibition/cell cytotoxicity of sealers on Vero cells, where, ZOE=Kalsogen Plus, $\mathrm{ER}=$ EndoREZ, and RS=RoekoSEAL.

\begin{tabular}{lllllll}
\hline \multicolumn{6}{c}{ \% Cell Cytotoxicity (Mean \pm SD) } \\
\hline Sealers & Fresh & 0hr & $24 \mathrm{hr}$ & $48 \mathrm{hr}$ & $72 \mathrm{hr}$ & 1 week \\
\hline ZOE & $2.71 \pm 0.93$ & $15.70 \pm 3.20^{\mathrm{a}}$ & $21.78 \pm 4.55^{\mathrm{a}}$ & $21.78 \pm 4.68^{\mathrm{a}}$ & $18.25 \pm 2.75^{\mathrm{a}}$ & $15.09 \pm 1.81^{\mathrm{a}}$ \\
ER & $2.71 \pm 0.79$ & $4.49 \pm 1.27^{\mathrm{b}}$ & $5.19 \pm 1.52^{\mathrm{b}}$ & $7.09 \pm 2.92^{\mathrm{b}}$ & $4.38 \pm 1.39^{\mathrm{b}}$ & $2.38 \pm 1.09^{\mathrm{b}}$ \\
RS & $2.89 \pm 0.28$ & $11.56 \pm 2.91^{\mathrm{ac}}$ & $11.63 \pm 3.06^{\mathrm{c}}$ & $19.33 \pm 5.53^{\mathrm{ac}}$ & $8.10 \pm 1.38^{\mathrm{bc}}$ & $10.02 \pm 2.66^{\mathrm{c}}$ \\
\hline
\end{tabular}

For each column, data with different letter superscripts denote significant difference $(\mathrm{p}<0.05)$. Overall comparison of effect of samples collected at different time interval showed that the mean value of ZOE was significantly higher as compared to all the other groups $(\mathrm{p}<0.05)$. The mean value of RS was found to be significantly lower to ZOE while it was significantly higher as compared to ER $(\mathrm{p}<0.05)$. Overall the increasing order of toxicity on Vero cells follows $-\mathrm{ER}<\mathrm{RS}<\mathrm{ZOE}$.

In overall assessment, extracts of Kalsogen Plus were more toxic, as compared to all other groups $(p<0.05)$ on both cell lines. Extracts of EndoREZ were least toxic and mean value of percentage inhibition was significant as compared to all the other groups on both cell lines. RoekoSeal had the minimum intergroup difference while the maximum difference was seen between Kalsogen Plus and EndoREZ.

Extracts of Kalsogen Plus and RoekoSeal were rated slightly cytotoxic, whereas extract of EndoREZ was noncytotoxic.

\section{Discussion}

The MTT Cell Proliferation Assay measures the cell proliferation rate and conversely, when metabolic events lead to apoptosis or necrosis, the reduction in cell viability. The number of assay steps has been minimized as much as possible to expedite sample processing. The MTT Reagent yields low background absorbance values in the absence of cells. For each cell type the linear relationship between cell number and signal produced is established, thus allowing an accurate quantification of changes in the rate of cell proliferation $[31,33]$.

The popularity of resin-based sealers is increasing, despite their well-documented toxicity and mutagenicity [34,35]. In addition, leakage has been observed between sealer and dentinal wall as a result of contraction of the resin sealers during setting [36]. Thus, new resin formulations have been designed to improve the adhesion of the sealers to dentine (EndoREZ). A sealer containing a single methacrylate has been described as well tolerated by connective tissues $[14,21]$. The sealer has shown biocompatibility to periapical tissues in subhuman primates [37] and to rat cells and bone tissue [22]. The results of the present study is in agreement with several other studies [14,21-23], but not with that by Bouillaguet et al., [24], where EndoREZ was found to be more cytotoxic than RoekoSeal when tested by the MTT assay. Urethane dimethacrylate (UDMA) in the structure of this sealer could be responsible for the cytotoxic effect, as it has been previously shown that UDMA is a toxic agent [38].

RoekoSeal is a new silicone-based material, which is described as a biocompatible material [39]. The findings of present study is in agreement with previous studies that showed that RoekoSeal was only slightly cytotoxic or completely non-cytotoxic even in fresh conditions $[15-17,23,40]$. It appears to be less cytotoxic than sealers based on methacrylate, zinc oxide-eugenol and epoxy resin [24]. However, another study rated the silicone-based sealer equal to an epoxy resinbased sealer in terms of cytotoxicity [25].

The setting of zinc oxide eugenol cements is a chemical process combined with physical embedding of zinc oxide in a matrix of zinc eugenolate. Analyses of the release of eugenol from set $\mathrm{ZnOE}$ cement showed that the oil is available only as the result of surface hydrolysis of the chelate [41-43]. Samples of $\mathrm{ZnOE}$ placed into saline showed an immediate release of eugenol from the $\mathrm{ZnOE}$ surface with the highest rate of release in the first seconds after contact, the release rate declined exponentially thereafter. In contrast, the release rate through intervening dentine was found to be entirely different. The release of eugenol was found to be much slower and could only be detected after several hours, it peaked after about a day and then declined slowly over several weeks. A sustained release occurred with the establishment of a relatively stable concentration gradient across the dentine which persisted for several months [44]. In the dentine immediately beneath the $\mathrm{ZnOE}$, the concentration of eugenol is sufficient to inhibit bacterial metabolism whilst the concentration in more remote dentine would be below the threshold for killing mammalian cells but at a sufficient level to exhibit pharmacological properties for which eugenol is renowned such as inhibition of nerve action potential [45] and prostaglandin synthesis [46]. If $\mathrm{ZnOE}$ contacts wetter tissue the release is more rapid, leading to the development of concentrations sufficient to kill cells. This explains the toxic effects of $\mathrm{ZnOE}$ when applied to wet tissues or to cells in culture.

The findings of the present study mostly corroborate with already reported toxicity profile of the sealers investigated. Whilst biocompatibility is a desirable quality, extrapolations to the clinical situation must be made with caution, as the results of such in vitro toxicity tests may not correlate with the in vivo response. 
Chandra et al. Oral Biology and Dentistry 2014,

\section{Conclusion}

EndoREZ was non cytotoxic amongst the sealer used. Kalsogen Plus and RoekoSEAL were slightly cytotoxic. The order of cytotoxicity was ZOE > RS>EZ.

\section{Competing interests}

The authors declare that they have no competing interests.

\section{Authors' contributions}

\begin{tabular}{|l|c|c|c|c|}
\hline Authors' contributions & AC & HR & AA & AV \\
\hline Research concept and design & $\checkmark$ & $\checkmark$ & $\checkmark$ & $\checkmark$ \\
\hline Collection and/or assembly of data & -- & $\checkmark$ & -- & -- \\
\hline Data analysis and interpretation & $\checkmark$ & $\checkmark$ & -- & -- \\
\hline Writing the article & $\checkmark$ & $\checkmark$ & -- & -- \\
\hline Critical revision of the article & $\checkmark$ & $\checkmark$ & $\checkmark$ & $\checkmark$ \\
\hline Final approval of article & $\checkmark$ & $\checkmark$ & $\checkmark$ & $\checkmark$ \\
\hline Statistical analysis & -- & -- & -- & -- \\
\hline
\end{tabular}

\section{Acknowledgement}

We thank Department of Endocrinology, Central Drug and Research Institute, Lucknow, India.

\section{Publication history}

EIC: Thimios A. Mitsiadis, University of Zurich, Switzerland.

Received: 28-Nov-2013 Revised: 09-Jan-2014

Accepted: 23-Jan-2014 Published: 01-Feb-2014

\section{References}

1. Branstetter $J$ and von Fraunhofer JA. The physical properties and sealing action of endodontic sealer cements: a review of the literature. $J$ Endod. 1982; 8:312-6. | Article | PubMed

2. Grossman LI. Endodontic Practice, 10th ed. Philadelphia: Henry Kimpton Publishers. 1981; 297.

3. Duarte MA, Ordinola-Zapata R, Bernardes RA, Bramante CM Bernardineli N, Garcia RB and de Moraes IG. Influence of calcium hydroxide association on the physical properties of AH Plus. J Endod. 2010; 36:1048-51. | Article | PubMed

4. Walton RE and Torabinejad M. Principles and Practice of Endodontics, 3rd ed. Philadelphia:Saunders. 2002.

5. Waltimo TM, Boiesen J, Eriksen HM and Orstavik D. Clinical performance of 3 endodontic sealers. Oral Surg Oral Med Oral Pathol Oral Radiol Endod. 2001; 92:89-92. | Article | PubMed

6. Geurtsen W. Biocompatibility of root canal filling materials. Aust Endod J. 2001; 27:12-21. | Article | PubMed

7. Bratel J, Jontell M, Dahlgren $U$ and Bergenholtz $G$. Effects of root canal sealers on immunocompetent cells in vitro and in vivo. Int Endod J. 1998; 31:178-88. | Article | PubMed

8. Silva-Herzog D, Ramirez T, Mora J, Pozos AJ, Silva LA, Silva RA and Nelson-Filho P. Preliminary study of the inflammatory response to subcutaneous implantation of three root canal sealers. Int Endod $\mathrm{J}$. 2011; 44:440-6. | Article | PubMed

9. Bernath $\mathrm{M}$ and Szabo J. Tissue reaction initiated by different sealers. Int Endod J. 2003; 36:256-61. | Article | PubMed

10. Hargreaves KM and Cohen S. Cohen's Pathways of the pulp 10th ed. Elsevier Inc. 2012; 656.

11. Ørstavic D. Materials used for root canal obturation: technical, biological and clinical testing. Endod Topic. 2005; 12:25-38. | Article

12. Nassri MRG, Bombana AC and Lia RCC. Apical and periapical tissues responses after root canal obturation with two calcium hydroxide based sealers in dog's teeth. RSBO. 2008; 5:50-56. | Article

13. Huang FM, Tai KW, Chou MY and Chang YC. Cytotoxicity of resin-, zinc oxide-eugenol-, and calcium hydroxide-based root canal sealers on human periodontal ligament cells and permanent V79 cells. Int Endod J. 2002; 35:153-8. | Article | PubMed

14. Zmener $\mathrm{O}$ and Pameijer $\mathrm{CH}$. Clinical and radiographic evaluation of a resin-based root canal sealer. Am J Dent. 2004; 17:19-22. | PubMed

15. Eldeniz AU, Mustafa K, Orstavik D and Dahl JE. Cytotoxicity of new resin-, calcium hydroxide- and silicone-based root canal sealers on fibroblasts derived from human gingiva and L929 cell lines. Int Endod J. 2007; 40:329-37. | Article | PubMed

16. Karapinar-Kazandag M, Bayrak OF, Yalvac ME, Ersev H, Tanalp J, Sahin $F$ and Bayirli G. Cytotoxicity of 5 endodontic sealers on L929 cell line and human dental pulp cells. Int Endod J. 2011; 44:626-34. | Article | PubMed

17. Lodiene G, Morisbak E, Bruzell E and Orstavik D. Toxicity evaluation of root canal sealers in vitro. Int Endod J. 2008; 41:72-7. | Article | PubMed

18. Adanir N, Cobankara FK and Belli S. Sealing properties of different resinbased root canal sealers. J Biomed Mater Res B Appl Biomater. 2006; 77:1-4. | Article | PubMed

19. Pameijer $\mathrm{CH}$ and $\mathrm{Zmener} \mathrm{O}$. Resin materials for root canal obturation. Dent Clin North Am. 2010; 54:325-44. | Article | PubMed

20.Zmener O, Pameijer CH, Serrano SA, Vidueira M and Macchi RL. Significance of moist root canal dentin with the use of methacrylatebased endodontic sealers: an in vitro coronal dye leakage study. J Endod. 2008; 34:76-9. | Article | PubMed

21.Zmener $\mathrm{O}$. Tissue response to a new methacrylate-based root canal sealer: preliminary observations in the subcutaneous connective tissue of rats. J Endod. 2004; 30:348-51. | Article | PubMed

22. Zmener $\mathrm{O}$, Banegas $\mathrm{G}$ and Pameijer $\mathrm{CH}$. Bone tissue response to a methacrylate-based endodontic sealer: a histological and histometric study. J Endod. 2005; 31:457-9. | Article | PubMed

23. Miletic I, Devcic N, Anic I, Borcic J, Karlovic Z and Osmak M. The cytotoxicity of RoekoSeal and AH plus compared during different setting periods. J Endod. 2005; 31:307-9. | Article | PubMed

24. Bouillaguet S, Wataha JC, Lockwood PE, Galgano C, Golay A and Krejci I. Cytotoxicity and sealing properties of four classes of endodontic sealers evaluated by succinic dehydrogenase activity and confocal laser scanning microscopy. Eur J Oral Sci. 2004; 112:182-7. | Article | PubMed

25. Oztan MD, Yilmaz S, Kalayci A and Zaimoglu L. A comparison of the in vitro cytotoxicity of two root canal sealers. J Oral Rehabil. 2003; 30:4269. | Article | PubMed

26. Schmalz G, Hoffmann M, Weis K and Schweikl H. Influence of albumin and collagen on the cell mortality evoked by zinc oxide-eugenol in vitro. J Endod. 2000; 26:284-7. | Article | PubMed

27. Hume WR. The pharmacologic and toxicological properties of zinc oxide-eugenol. J Am Dent Assoc. 1986; 113:789-91. | Article | PubMed

28. Wilson AD, Clinton DJ and Miller RP. Zinc oxide-eugenol cements. IV. Microstructure and hydrolysis. J Dent Res. 1973; 52:253-60. | Article | PubMed

29. Hensten-Pettersen A and Helgeland K. Evaluation of biologic effects of dental materials using four different cell culture techniques. Scand J Dent Res. 1977; 85:291-6. | Article | PubMed

30. Brodin P. Neurotoxic and analgesic effects of root canal cements and pulp-protecting dental materials. Endod Dent Traumatol. 1988; 4:1-11. | Article I PubMed

31. Mosmann T. Rapid colorimetric assay for cellular growth and survival: application to proliferation and cytotoxicity assays. J Immunol Methods. 1983; 65:55-63. | Article | PubMed

32. Dahl JE, Frangou-Polyzois MJ and Polyzois GL. In vitro biocompatibility of denture relining materials. Gerodontology. 2006; 23:17-22. | Article I PubMed

33. van Meerloo J, Kaspers GJ and Cloos J. Cell sensitivity assays: the MTT assay. Methods Mol Biol. 2011; 731:237-45. | Article | PubMed

34. Schweikl H, Schmalz G and Federlin M. Mutagenicity of the root canal 
sealer AHPlus in the Ames test. Clin Oral Investig. 1998; 2:125-9. | Article | PubMed

35. Huang FM, Tai KW, Chou MY and Chang YC. Cytotoxicity of resin-, zinc oxide-eugenol-, and calcium hydroxide-based root canal sealers on human periodontal ligament cells and permanent V79 cells. Int Endod J. 2002; 35:153-8. | Article | PubMed

36. De Almeida WA, Leonardo MR, Tanomaru Filho M and Silva LA. Evaluation of apical sealing of three endodontic sealers. Int Endod J. 2000; 33:25-7. | Article | PubMed

37. Louw NP, Pameijer $\mathrm{CH}$ and Norval G. Histopathological evaluation of a root canal sealer in subhuman primates. J Dent Res. 2001; 80: 654. I Article

38. Hikage S, Sato A, Suzuki S, Cox CF and Sakaguchi K. Cytotoxicity of dental resin monomers in the presence of $\mathbf{S 9}$ mix enzymes. Dent Mater J. 1999; 18:76-86. | Article | PubMed

39. Scelza MZ, Coil J and Alves GG. Effect of time of extraction on the biocompatibility of endodontic sealers with primary human fibroblasts. Braz Oral Res. 2012; 26:424-30. | Article | PubMed

40. Schwarze T, Leyhausen $G$ and Geurtsen W. Long-term cytocompatibility of various endodontic sealers using a new root canal model. J Endod. 2002; 28:749-53. | Article | PubMed

41. Wilson AD and Batchelor RF. Zinc oxide-eugenol cements: II. Study of erosion and disintegration. J Dent Res. 1970; 49:593-8. | Article PubMed

42. Becker RM, Hume WR and Wolinsky. Release of eugenol from mixture of zinc oxide and eugenol in-vitro. J Pedodont. 1983; 8:71.

43. Hume WR. Effect of eugenol on respiration and division in human pulp, mouse fibroblasts, and liver cells in vitro. J Dent Res. 1984; 63:1262-5. | Article | PubMed

44. Hume WR. In vitro studies on the local pharmacodynamics, pharmacology and toxicology of eugenol and zinc oxide-eugenol. Int Endod J. 1988; 21:130-4. | Article | PubMed

45. Brodin P and Orstavik D. Effects of therapeutic and pulp protecting materials on nerve transmission in vitro. Scand J Dent Res. 1983; 91:4650. | Article | PubMed

46. Dewhirst FE. Structure-activity relationships for inhibition of prostaglandin cyclooxygenase by phenolic compounds. Prostaglandins. 1980; 20:209-22. | Article | PubMed

\section{Citation:}

Chandra A, Rahman H, Agarwal A and Verma A.

Toxicity of root canal sealers in vitro. Oral Biol Dent. 2014; 2:2. http://dx.doi.org/10.7243/2053-5775-2-2 